\title{
CONSERVATION ISSUES AT THE Watson Pinelands Preserve, Tyler County, TeXas
}

\author{
Michael Howlett • Naturalist, Jesse H. Jones Park \& Nature Center • 20634 Kenswick Dr. \\ - Humble, TX・USA・mhowlett@hcp4.net.
}

Keywords: conservation: Texas, Watson Pinelands Preserve, Sarracenia alata

\begin{abstract}
The Watson Pinelands Preserve (527 County Road 4777, Warren, Texas 77664 (409) 3857239 or (409) 547-3543) is a 4.8-ha (12-ac) privately owned facility nestled in the Big Thicket of east Texas, and is home to many species of carnivorous plants. Development and maintenance of the preserve as a living record of the rich diversity of East Texas herbaceous and woody plants has not been an easy task, and has had its share of conservation issues as well. This article will discuss some of the many conservation issues that affect the Watson Pinelands Preserve, and what can be done to reduce and/or eliminate some of these effects.
\end{abstract}

\section{Discussion}

The Watson Pinelands Preserve is a small privately-owned 4.8-ha (12-ac) nature sanctuary in the piney woods of Tyler County, Texas. It is owned and maintained by Ms. Geraldine Watson. Ms. Watson has spent her entire life in the area, and has dedicated the preserve to the memory of her late husband. The preserve serves as a showcase of the floral diversity that was historically found in the area. This entire portion of east Texas has been collectively referred to as the Big Thicket, a region renowned for its rich biodiversity and dense plant growth. Visitors to the Watson Pinelands Preserve can begin their visit in a Longleaf Pine Savannah, traverse a footbridge across a small creek lined with wild native swamp azaleas, Rhododendron viscosum, stroll through a fern forest, and finish in a Sphagnum bog, all in the space of a few hundred meters.

The preserve has many other plant associations represented as well, including BeechMagnolia-Loblolly Slopes, Baygall Bogs, and true aquatic habitats like the azalea creek mentioned above and Hyatt Lake, which forms the southern boundary of the preserve. Because of this, visitors to the Watson Preserve can see everything from towering southern magnolias, Magnolia grandiflora, American beeches, Fagus grandifolia, and longleaf pines, Pinus palustris; to diminutive orchids (Calapogon, Habenaria, Pogonia and others), beechdrops, Epifagus virginiana, violets, Viola sp., and Sphagnum sp. Botanical rarities like Scarlet Catchfly, Silene subciliata, and several species of fringed orchids, Platanthera sp., can be seen at certain times of the year. Of course, a wealth of animals also frequent the preserve, including many species of resident and migratory birds, butterflies, odonates, reptiles, mammals, and other fauna.

The preserve is a serene setting for painting, relaxing, outdoor activities, nature viewing, and other passive recreation. Although privately owned, the preserve has no entrance fees or fencing, making it accessible to visitors at all times free of charge. So for those enlightened individuals who enjoy viewing carnivorous plants in the wild, the preserve is a wealth of visual beauty which can be visited at any time. Drosera brevifolia, D. capillaris, Pinguicula pumila, Utricularia subulata, U. gibba, and U. cornuta can all be seen here at various times of the year, as well as several appreciable stands of Sarracenia alata.

As you might have already discerned, there are many issues involved with conserving and maintaining this jewel of east Texas. Some of the most detrimental issues involve direct human problems, but issues can also arise from lack of funding and manpower. For instance, since the preserve is privately owned and charges no admission, funding issues have hindered Ms. Watson's efforts to purchase adjacent undeveloped parcels of land. But after the new millennium, she managed to assemble the funds needed to purchase additional land adjacent to the existing preserve. Land acquisitions can add unique features to the existing preserve, but just as importantly, they can provide buffer zones between the preserve and neighboring developed areas.

One of the first obstacles to overcome on this new land was the elimination of four-wheeler traffic. Numerous four-wheeler trails coursed through and across the new property, and this also 
allowed for uncaring individuals to use the property as a dumping ground for all kinds of refuse, up to and including old tires, plastics, and even a few appliances! Of course, this property was privately owned prior to its acquisition by Ms. Watson; but there seem to be no shortage of ignorant individuals who think that the world is their personal dump and playground. It took some time to make sure everyone realized that this was no longer just an undeveloped piece of property; this was now part of the preserve, and that motorized vehicles and dumping were not permitted.

While this land had not been maintained for many years, Ms. Watson's keen eye for the land's potential soon created a vision of a longleaf pine savannah encompassing the existing centrally located spring-fed pool. In the summer of 2003, a group of volunteers met to begin transforming the new property. Initial work involved manually removing undesirable plant species, predominantly Leatherwood, Cyrilla racemiflora, and then using fire to remove and retard this and other species. Fire is a commonly used tool at the preserve, but not necessarily during the heat and humidity of an east Texas summer day. Needless to say, volunteers were especially mindful of the risk of heat-related injuries!

Once the area was cleared, a number of mature $S$. alata divisions and other plants were moved from the existing Sphagnum bog to this new area. With these optimum conditions, these plants flourished. However, what was amazing to the author was the number of volunteer $S$. alata seedlings which came up as well once the area was opened up. These seeds must have been here for quite some time, waiting for the proper conditions for growth!

Of special importance to naturalists, and especially carnivorous plant enthusiasts, is the introduction of non-native species. As with much of the Gulf Coast region, the Big Thicket has its share of issues with high visibility invasive species such as Chinese tallow, Triadica sebifera, Asian species of privet, Ligustrum sp., and deep-rooted sedge, Cyperus entrerianus. But in 2001 or 2002, some thoughtless individual took it upon themselves to plant a white-topped pitcher plant, Sarracenia leucophylla, into the original stand of pure, native Texas Sarracenia alata at the Watson Pinelands Preserve. This went unnoticed until 2004, and by this time the S. leucophylla plant had cross-pollinated a number of $S$. alata. The author discussed the problem with Ms. Watson, explaining that although this might seem acceptable - since it added a few beautiful red colored inflorescences to the stand, and is a naturally occurring hybrid ( $S$. areolata) in other parts of the Gulf Coast - the damage to the genetic purity of this native Texas $S$. alata stand was irreversible. Additionally, the pollen from this $S$. leucophylla and its hybrids might be carried to other pure $S$. alata sites, including those in the Big Thicket National Preserve! Ms. Watson agreed to allow the removal of the non-native $S$. leucophylla and all hybrids, and this work has been conducted each spring, when the hybrids are differentiated by their red or reddish petals, since that time. The removal efforts have many benefits: hybrids are removed, maintaining the pure appearance of the stand, particularly during the spring blooming period; removed plants are offered to interested individuals, in return for donations to the Watson Pinelands Preserve; and the donations are used to help maintain the preserve's boardwalks and other amenities. This is a win-win situation for all.

This hybridization dilemma, though, has also been thought-provoking for me personally in several ways. First of all, if this stand had been represented as a genetically distinct group of plants in a botanical program of some sort prior to the introduction of the non-native S. leucophylla, there would have been the opportunity - slim as it may be - to remove all of the $S$. alata and hybrid plants from the site, thereby eliminating any chance of hybrid genetic material to remain. Once the risk of hybrids was removed in this manner, genetically pure specimens from the botanical program could be reintroduced back into the site. This was the impetus for my involvement as the national head grower for the North American Sarracenia Conservancy, a new nonprofit organization whose mission is to "serve as a living record of the taxonomic, morphological and genetic diversity of the genus Sarracenia for purposes of conservation and cultivation." More information about this dynamic organization may be viewed at www.nasarracenia.org.

Another hybridization dilemma has been the thought of what effect a minimal amount of $S$. leucophylla genetic material might have on the morphology of specimens of S. alata. Flower petal color may usually be deep red in pure $S$. leucophylla; but as the $S$. areolata hybrids continue to outcross with $S$. alata (which usually has pure greenish yellow petals), the petal color becomes less and less red. Eventually, it may be extremely difficult to use simple morphological petal differences to differentiate between pure $S$. alata and the hybrids. Couple this with the fact that the petals in some stands of $S$. alata already show a reddish blush, and there is room for doubt 
as to the genetic integrity of some of these plants. Sarracenia alata petals with reddish casts have been observed in wild stands in the eastern portion of its range, and in Jasper County, Texas (B. Rice, pers. comm.), where a rare 'windowed' variant of $S$. alata exists. But at what point do you cease to be able to differentiate the genetically pure native $S$. alata from the hybrids? Are these plants with blushed petals and windowed pitchers pure $S$. alata, or a hybrid that has been outcrossed for decades, or even centuries? In the author's opinion, further genetic study is needed to resolve this issue.

Another important issue is that of maintenance. Lack of adequate funds, compounded by the preserve's private status, can cause smaller, less used features of the preserve to go without proper repairs. Many of the bridges and walkways cover only short distances. But several hundred meters of boardwalk can be difficult to maintain, both financially and physically, especially by a widowed woman in her eighties. There are occasional minimal donations of materials and/or labor by private individuals and nonprofit volunteer groups, but this is not sufficient to maintain the boardwalks in a good state of repair at all times, let alone the many other facets of the preserve. Additional funding and volunteers must be found if the preserve is to survive in Ms. Watson's absence.

Winter ice storms and tropical storms can take their toll on conservation efforts as well. Damage to trees caused by ice buildup, and the sustained high winds of tropical systems moving inland, can cause an incredible amount of combustible material to accumulate on the ground. This hampers the ability to conduct prescribed burns, or control those that are conducted, as easily. Too much fuel can be a very dangerous situation. As is the case with many other natural sites containing a large percentage of herbaceous flora, one of the most important methods to control overgrowth is through the use of prescribed burns. Prescribed burns keep large amounts of fuel from building up to dangerous levels, help control or remove unwanted woody growth in sensitive areas, and help turn herbaceous growth and deadfall into nutrients for the next year. At no other time has this been more evident than in the aftermath of Hurricane Rita, which devastated the entire east Texas and western Louisiana area. Scores of trees were downed throughout the preserve, and the amount of deadfall buildup increased significantly. Although the trees were cut into smaller sections and moved when possible, an incredible amount of material was still left behind. This reduced the ability to conduct an efficient burn in 2006, which resulted in an increase in undesirable growth as well. Fortunately, everything is on track for a better prescribed burn in 2007!

Prescribed burns can have some negative effects as well. The sheer heat produced during a burn can kill desirable species as well, and more than one rare tree or herbaceous plant at the preserve has been damaged or even destroyed by the fire's heat. As you might also surmise, it isn't always easy to convince your neighbors that setting the forest on fire is a good thing. The risk of having a fire escape across a fire lane is always present, and the ramifications of such an event can be financially devastating. Wildfires can be caused by escaped burns, and the Watson Pinelands Preserve is surrounded by a densely forested neighborhood. It wouldn't take much to financially ruin this 'diamond in the rough.'

The smoke from a burn can be equally concerning, by causing problems for wildlife, neighbors and even air traffic. Precautions must be taken to make sure the appropriate agencies know that the burn is a planned event, and not a wildfire. The immediate aftermath is not always viewed in a kindly light either, since the appearance of the blackened ground, charred bark on the longleaf pines, and days of smoldering deadfall at the preserve is not necessarily the best way to attract visitors. But for those who understand the burn's purpose and are patient, it doesn't take long for the barren patch of land to begin anew. Each spring produces an astounding visual display of flowers, ferns, and fauna for all to enjoy, and with the wealth of flora represented here, the Watson Pinelands Preserve is sure to give visitors a breathtaking display, no matter what time of year you care to visit.

ADDITIONAL NOTES AS OF THIS PRINTING (March 2010): This paper was presented at the 6th Conference of International Carnivorous Plant Society, June 1-5, 2006, Frostburg, Maryland, USA. As of January 2009, the preserve has obtained its federal 501(c)3 status, and is now known as the Watson Rare Plants Preserve. Prescribed burns are being held annually when conditions permit, and the condition of the preserve's habitats seems as good as ever. However, Hurricanes Rita and Ike were not kind to the manmade structures at the preserve, especially the walking boardwalks in the pitcher plant bogs, and funding for this gem is still minimal. Please consider making a tax-deductible donation to this beautiful corner of the Big Thicket! 